\title{
PENCIPTAAN SENI KRIYA LOGAM KREATIF DENGAN MEMANFAATKAN LIMBAH ONDERDIL KENDARAAN
}

\author{
Titiana Irawani dan Budi Hartono *)
}

\begin{abstract}
Industri kreatif adalah industri yang berasal dari pemanfaatan kreativitas dan ketrampilan serta bakat individu untuk menciptakan kesejahteraan serta lapangan pekerjaan melalui daya kreasi dan daya cipta individu tersebut. Artikel ini merupakan hasil penelitian yang dilaksanakan bertujuan untuk memanfaatkan limbah onderdil kendaraan yang berupa skrup, baut, rantai, gir, blog mesin, dan lain-lain menjadi sebuah karya kriya logam yang kreatif-inovatif. Selain itu juga untuk meningkatkan nilai tambah secara ekonomis, dari semula limbah yang umumnya dijual murah dengan harga kiloan, menjadi produk seni kriya yang memiliki nilai artistik dengan harga yang tinggi. Produk yang diciptakan adalah produk-produk fungsional atau home decorative.
\end{abstract}

Kata Kunci: kriya logam, kreatif, limbah onderdil

\section{PENDAHULUAN}

Perkembangan kendaraan di Indonesia dari tahun ke tahun semakin meningkat pesat, baik jenis, tipe maupun kuantitasnya. Hal ini pada satu sisi tentu saja memberikan indikator yang baik karena menandakan bahwa kesejahteraan rakyat Indonesia semakin meningkat. Akan tetapi, pada sisi yang lain situasi tersebut juga menimbulkan persoalan contohnya adalah kemacetan. Saat ini tidak hanya di Jakarta saja, kemacetan juga telah melanda kotakota lain di Indonesia, seperti Bandung dan Surabaya. Selain persoalan tersebut, hal yang sering kali tidak terpikirkan adalah semakin banyaknya pula limbah rongsokan onderdil kendaraan. Limbah kendaraan bermotor dapat digolongkan menjadi dua yaitu logam dan non logam. Limbah non logam berupa ban, karet-karet, dan lainnya. Sedangkan limbah logam terdiri dari logam besi dan logam lain seperti aluminium dan kuningan. Limbah padat logam umumnya dimanfaatkan kembali atau di daur ulang dengan melalui proses peleburan. Bisnis limbah logam saat ini telah memunculkan rantai perdagangan yang melibatkan masyarakat luas, terutama sebagai pengumpul dan pengepul rongsokan onderdil logam. Harga limbah logam di pasar rongsokan berkisar antara Rp. 6.000,sampai dengan Rp. 10.000,- tergantung pada jenis logam dan ketebalan logam.

Limbah logam kendaraan umumnya dalam pengelolaan menjadi kendala tersendiri, meskipun rongsokan itu dengan mudah dijual dengan harga dibawah harga logam pada umumnya. Hal ini karena stigma terhadap logam tersebut sebagai barang bekas atau rongsokan. Jika tidak berhati-hati dalam pengolahan, logam limbah itu akan terjadi korosi yang mengakibatkan buruknya nilai atau kualitas logam. Meskipun limbah logam tersebut telah di daur ulang dengan cara peleburan yang pada satu sisi memiliki efektivitas yang baik, namun nilai (value) yang dihasilkan kurang memadai, karena biasanya sebelum proses peleburan tidak dilakukan pengecekan kualitas limbah

\footnotetext{
* Titiana Irawani (titiana.irawani@yahoo.com), Budi Hartono (baworbudi@gmail.com) Staf Pengajar di Jurusan Kriya Fakultas Seni Rupa Institut Seni Indonesia Yogyakarta
} 
logam, sehingga kualitasnya tidak akan sama antara logam satu dengan yang lain.

Upaya pengelolaan limbah yang akan dilakukan adalah dengan membuat karya seni kriya berbasis limbah kendaraan terutama limbah logam berjenis besi. Seni kriya memiliki fleksibilitas dalam menentukan bentuk dan teknik yang digunakan. Selain itu, bahan tersebut memiliki kekuatan dan keuletan karena terbuat dari logam dan mudah untuk di las. Kekuatan bahan yang demikian, mampu dibuat karya kriya yang artistik dan menarik. Sehingga limbah itu dapat dihadirkan menjadi bentuk lain dari bentuk yang biasanya terlihat. Inilah yang membuat karya kriya berbahan limbah ini akan memiliki nilai artistik dan nilai ekonomis yang tinggi, bahkan bisa sampai 2 kali lipat dari harga limbah.

Penambahan nilai artistik akan memberikan pengaruh pada sesuatu yang kurang dan dianggap sampah menjadi sesuatu yang bermakna. Kecenderungan pasar seni kriya tahun 2016 akan banyak menggunakan logam sebagai produk home assesories, setidaknya trend forecast tersebut terlihat dalam beberapa bulan terakhir pada beberapa pameran yang diselengggarakan di Kanton Fair di Cina maupun IFFINA di Jakarta. Prospek yang terlihat adalah munculnya karya-karya retro yang merupakan representasi dari barangbarang yang dianggap usang, bekas dan tampak tidak ada nilainya. Bahkan beberapa petunjuk desain dari kelompok Enrico Vakety di Itali menghadirkan berbagai variasi logam lama yang mampu menembus pasar Eropa dalam dua tahun belakangan. Oleh karena itu, penciptaaan seni kriya logam berbahan limbah onderdil kendaraan ini memiliki peluang yang besar dalam memberikan pengaruh desain dari onderdil dengan teknik kolase, maka akan di dapat hasil yang artistik dan menarik. Keunikan akan dilihat dari bagaimana teknik penyusunan logam itu satu demi satu membentuk sebuah benda seni yang memiliki nilai jual tinggi. Rumusan permasalahan dalam pencitaan ini adalah:

a. Bagaimanakah menciptakan produk seni kriya logam berbasis bahan limbah logam onderdil kendaraan?

b. Bagaimanakah desain, proses perwujudan, prototipe dan uji pasar bagi produk seni kriya logam onderdil kendaraan?

\section{METODE PENCIPTAAN}

Penelitian ini adalah untuk menghasilkan seni kriya logam baru menggunakan frame estetis dan ekonomis. Pendekatan estetis adalah proses eksplorasi mencari bentuk yang artistik dan kreatif, dan ekonomis adalah kemampuan produk itu dalam memberikan dampak ekonomi pada masyarakat pengrajin. Adapun alur prosesnya sebagai berikut,

\section{Studi Pustaka dan Observasi}

Studi pustaka dan observasi untuk pengumpulan data dan informasi yang diperlukan sesuai dengan masalah penelitian, yakni masalah eksplorasi desain dan potensi bahan limbah logam kendaraan serta ketrampilan lokal, serta karater finishing agar sesuai dengan minat konsumen.

\section{Perwujudan}

Perwujudan adalah proses menvisuali-sasikan ide-konsep yang didapat dari hasil penelitian awal. Melalui eksplorasi dan eksperimentasi diterjemahkan dalam sketsa alternatif, eksperimen bentuk, penentuan bentuk, dan finishing produk. Tahapan dari proses pembentukan persiapan bahan, persiapan alat, proses pembentukan teknik kolase, pengelasan, dan finishing. Selama proses perwujudan prototype dilakukan pengamatan dan pencatatan sehingga dapat menghasilkan produk seni kriya logam yang sesuai dengan minat konsumen. 


\section{Uji kelayakan pasar}

Yakni memperkenalkan produk pada konsumen, yakni mengadakan uji pasar melalui mendisplay pada art-shop yang kemudian diadakan uji representasional dengan melakukan penilaian dari dekat dengan pasar baik produsen maupun eksportir. Uji coba pengukuran pasar ini menjadi teknik riset baik untuk mengurangi resiko yang ada pada produk baru dan menilai keberhasilannya dengan mengukur ketertarikan mereka. Metode yang digunakan dalam uji coba pasar adalah menilai sejauhmana penerimaan calon pembeli bisa diamati dan dianalisis lebih dekat.

Analisis yang digunakan adalah analisis diskriptif kualitatif, sementara untuk mengetahui jumlah dan nominal peningkatan penjualan produk baru dalam skala pasar akan disinggung juga analisis kuantitatif. Seluruh data yang diperoleh akan dianalisis disajikan secara naratif dan data yang berupa hasil penelitian akan disajikan dalam bentuk gambar. Sebagai upaya menjaring konsumen atas produk baru yang menggunakan limbah logam ini. Sosialisasi akan melibatkan pihak-pihak terkait baik swasta UMKM maupun pemerintah.

\section{HASIL DAN PEMBAHASAN}

\section{Eksplorasi Limbah Onderdil Kendaraan}

Limbah merupakan buangan yang dihasilkan dari penggunaan atau konsumsi baik dari industri maupun perorangan. Limbah sangat banyak sekali macam jenis, maupun sifatnya. Limbah biasanya dikategorikan menjadi dua jenis yaitu limbah padat dan limbah cair. Salah satu limbah yang perlu penanganan khusus dalam perlakuan maupun pembuangannya adalah limbah yang dikategorikan B3, yaitu bahan berbahaya dan beracun. Jika limbah tersebut tidak diberikan penanganan khusus maka akan berdampak pada kelestarian lingkungan dan kesehatan manusia.
Persoalan lain yang umum terkait limbah, terutama limbah padat adalah permasalahan kapasitas atau daya tampung tempat pembuangan limbah. Limbah yang tiap hari terus menerus bertambah akan mengakibatkan daya tampung lahan yang semakin berkurang. Hal tersebut dikarenakan limbah padat kebanyakan merupakan material yang tidak gampang terurai. Limbah padat tersebut diantaranya adalah yang terbuat dari plastik, karet, maupun logam.

Salah satu jenis limbah padat yang akhir-akhir ini semakin meningkat adalah limbah padat dari hasil perkembangan industri otomotif yang semakin berkembang. Limbah padat komponen atau onderdil kendaraan bermotor dapat dikategorikan menjadi dua, yaitu logam dan non logam (plastik, karet). Limbah logam umumnya didaur ulang (recycle) dengan cara dilakukan peleburan. Bengkel-bengkel kendaraan bermotor menjual limbah onderdil logam ke para pengepul untuk kemudian dilebur dan dicetak menjadi barang baru. Limbah logam yang dijual oleh bengkel-bengkel kendaraan bermotor ke pengepul biasanya dibeli kiloan dengan harga yang sangat murah. Padahal jika limbah logam tersebut dimanfaatkan ulang (reuse) baik untuk fungsi yang sama maupun berbeda, maka harga jualnya dapat lebih tinggi lagi. Hal ini sejalan dengan penelitian Kosasih dan Mattjik (2015), yang menyatakan bahwa limbah onderdil logam yang dimanfaatkan ulang menjadi produk souvenir dapat ditingkatkan potensi harga jualnya $7 x-12 x$ daripada hanya dijual kiloan. Berikut ini tabel proyeksi peningkatan 
penghasilan menurut penelitian Kosasih dan Mattjik (2015):

Tabel 1 Proyeksi Peningkatan Penghasilan

\begin{tabular}{|c|c|c|c|c|c|}
\hline $\begin{array}{l}\text { Jenis Limbah } \\
\text { Non Rekondisi }\end{array}$ & Proses sekarang & $\begin{array}{l}\text { Pendapatan } \\
\text { Pengrajin }\end{array}$ & $\begin{array}{c}\text { Proses Penambahan } \\
\text { Nilai }\end{array}$ & $\begin{array}{c}\text { Harga Jual Sesudah } \\
\text { Proses Penambahan } \\
\text { Nilai } \\
\end{array}$ & $\begin{array}{c}\text { Potensi } \\
\text { Peningkatan Nilai }\end{array}$ \\
\hline \multirow{4}{*}{ Ban Bekas } & \multirow{4}{*}{$\begin{array}{l}\text { Dijual ke } \\
\text { pembakaran } \\
\text { kapur }\end{array}$} & \multirow{4}{*}{ Rp. $1000 /$ buah } & $\begin{array}{l}\text { Di buat sabuk ikat } \\
\text { pinggang }\end{array}$ & $\begin{array}{l}\text { Rp. } 5000 \text { - Rp. } 10.000 / \\
\text { buah }\end{array}$ & $5 x-10 x$ lipat \\
\hline & & & Di buat meja- kursi & $\begin{array}{l}\text { Rp. } 30.000 \text { - Rp. } \\
50.000 / \text { buah }\end{array}$ & $30 x-50 x$ lipat \\
\hline & & & Karet Dudukan mesin & $\begin{array}{l}\text { Rp. } 500 \text { - Rp. } 1000 / \text { buah } \\
\text { ( } 1 \text { buah ban }=20 \text { buah } \\
\text { karet dudukan) }\end{array}$ & $10 x-20 x$ lipat \\
\hline & & & Di buat serbuk karet & $\begin{array}{l}\text { Rp. } 10.000- \\
\text { Rp. } 12.000 / \mathrm{kg} \\
\text { (rata-rata } 2 \text { buah ban = } 1 \\
\text { kg serbuk karet) }\end{array}$ & $5 x-6 x$ lipat \\
\hline \multirow{2}{*}{$\begin{array}{l}\text { Plastik Body } \\
\text { Motor }\end{array}$} & \multirow{2}{*}{$\begin{array}{l}\text { Di jual ke } \\
\text { pengepul }\end{array}$} & \multirow[b]{2}{*}{ Rp.2000/kg } & Di buat serbuk plastik & Rp. 10000-Rp.14000/kg & $5 x-7 x$ lipat \\
\hline & & & Di buat mainan anak & $\begin{array}{l}\text { Rp. } 30.000-R p .50 .000 / \\
\text { buah }\end{array}$ & $15 x-25 x$ lipat \\
\hline \multirow{2}{*}{$\begin{array}{l}\text { Logam } \\
\text { sparepart }\end{array}$} & \multirow{2}{*}{$\begin{array}{l}\text { Di jual ke } \\
\text { pengepul }\end{array}$} & \multirow[b]{2}{*}{ Rp.4000/kg } & Di buat serbuk logam & Rp. $16.000-R p 20.000 / \mathrm{kg}$ & $4 x-5 x$ lipat \\
\hline & & & Di buat souvenir & $\begin{array}{l}\text { Rp.30.000-Rp. } 50.000 / \\
\text { buah }\end{array}$ & $7 x-12 x$ lipat \\
\hline
\end{tabular}

Pasar onderdil bekas di Yogyakarta sangat banyak, tersebar di berbagai tempat, diantaranya ada di Pasar Beringharjo, pasar klitikan (barang bekas) Pakuncen di kota Yogyakarta, pasar klitikan jejeran Bantul dan lainnya. Onderdil bekas yang di jual di pasar tersebut sangat beragam, tidak hanya bekas onderdil kendaraan roda dua saja, tetapi juga mobil. Jenisnya pun beragam, dari onderdil yang ukurannya besar seperti blok mesin, sampai yang kecil-kecil seperti mur, baut, dan gir motor. Masyarakat yang menginginkan harga onderdil rekondisi yang masih bisa dipakai dengan harga yang murah biasanya mencari di pasar onderdil bekas tersebut.

Yogyakarta tercatat merupakan salah satu kota di Indonesia yang pertumbuhan kendaraannya cukup tinggi. Sebagai kota pelajar, dimana semakin banyak siswa maupun mahasiswa dari berbagai daerah melanjutkan studinya di kota ini, ternyata juga berbanding lurus dengan peningkatan prosentase kendaraan yang ada di Yogyakarta. Hal inilah yang kemudian membawa konsekuensi semakin meningkatnya pula limbah onderdil atau komponen kendaraan bermotor.

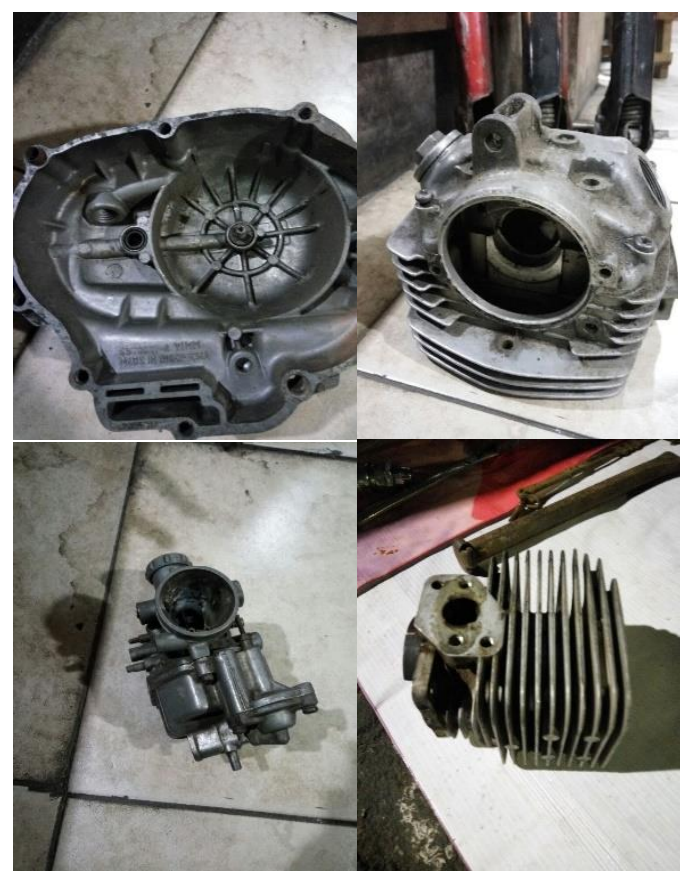

Gambar 1. Berbagai Jenis Onderdil Bekas Kendaraan Bermotor

Berbagai onderdil bekas yang dijual di pasar klitikan, ada yang masih bisa digunakan meskipun kondisinya tidak seratus persen, ada pula yang tidak lagi dapat digunakan sesuai fungsi utamanya. Oleh karena itu perlu pemikiran yang kreatif agar onderdil bekas, terutama yang materinya terbuat dari logam tersebut dapat digunakan lagi (reuse) untuk fungsi yang 
berbeda. Melimpahnya bahan baku onderdil bekas ini dapat menjadi faktor pendukung untuk produksi barang-barang kerajinan atau kriya utamanya yang berbasiskan material logam.

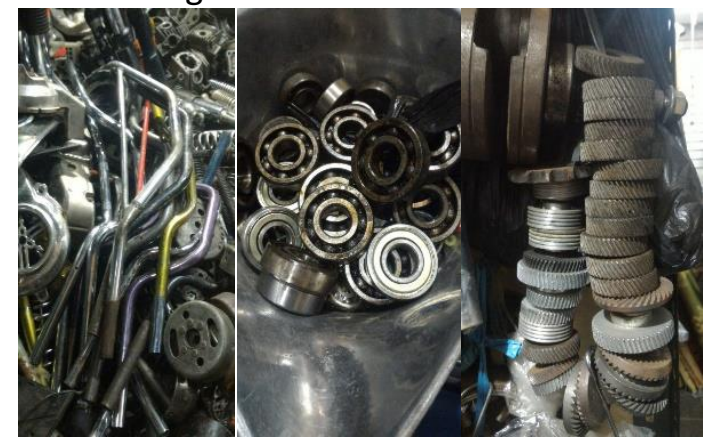

Gambar 2. Onderdil Bekas Kendaraan Bermotor yang Dapat di Reuse

\section{PERANCANGAN DESAIN PRODUK KRIYA LOGAM}

\section{Analisis Data Tren Desain}

Penerapan tren desain pada suatu produk merupakan upaya untuk membuat suatu inovasi yang disesuaikan dengan gaya hidup (lifestyle) konsumen yang selalu berubah. Inovasi produk biasanya lebih menyentuh pada aspek fungsi, tampilan, bahan dan teknik produksi. Tampilan produk merupakan daya tarik pertama bagi konsumen, baik dari segi warna, bentuk, tekstur maupun detail hiasan. Berdasarkan hal tersebut maka kreativitas desainer pada sisi penampilan produk akan sangat menentukan daya tarik produk bagi konsumen.

Pada era industri kreatif saat ini, produk-produk yang memiliki unsur kreatifitas, keunikan dan kekhasan semakin menarik konsumen dari waktu ke waktu. Para kreator semakin dituntut untuk membuat produk dengan konsep atau ide yang unik dan didukung dengan ketrampilan craftmanship yang mumpuni. Konsep produk dapat digali dari berbagai sumber, misalnya dari karakter etnik budaya sehingga memunculkan lokalitas entitas budaya, juga dapat pula dari perkembangan peradaban yang memunculkan budaya baru.
Kemajuan teknologi yang berkembang dewasa ini memunculkan budaya-budaya baru yang tentu saja tidak akan didapatkan pada masa lalu. Misalnya tentang penggunaan gadget seperti komputer, smartphone, dan internet memunculkan masyarakat digital yang cara berinteraksi dan berkomunikasinya tidak lagi dibatasi oleh ruang dan waktu. Masyarakat saat ini dapat dengan mudahnya mencari referensi dan membandingkan produk satu dengan yang lain dalam pengambilan keputusan pembeliannya. Selain itu juga muncul kebutuhan akan produk-produk yang lebih personal, sesuai dengan keinginan, selera, dan gaya hidupnya.

Saat ini muncul tren yang mengarah pada karakter Tekno-Urban. Karakter ini dimiliki oleh kelompok masyarakat yang hidup di perkotaan dengan basis gaya hidup kontemporer (Bidisi, 2015). Karakter TeknoUrban ini tercermin pada selera masyarakatnya sebagai berikut:

a) Gaya visual lebih menonjol daripada aspek kenyamanan.

b) Unsur teknologi sangat berpengaruh pada fungsi dan gaya, terutama teknologi informasi dan digital.

c) Konsumen tidak terlalu suka pada mass product, sehingga produk semakin mendekati personalisasi penggunanya.

d) Batas-batas ruang ditipiskan, misalnya penyatuan ruang indoor dengan outdoor yang memerlukan produk dengan spesifikasi gabunan antara keduanya.

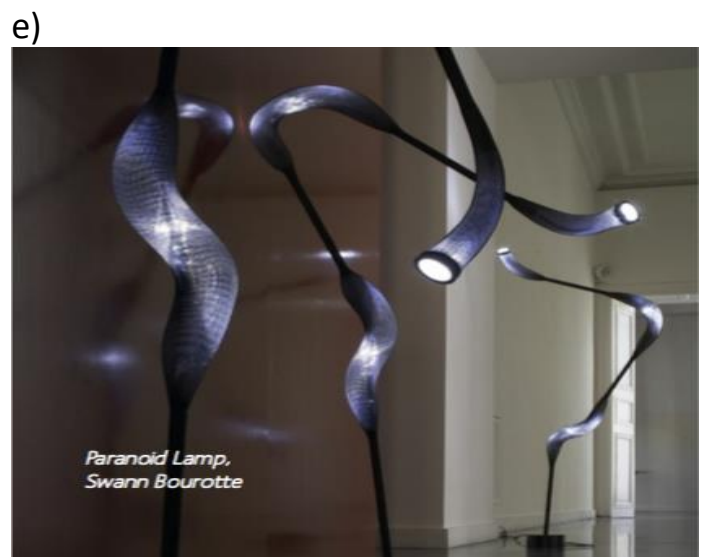

Gambar 3. Paranoid Lamp (Sumber: Bidisi, 2015) 
Pada contoh produk paranoid lamp karya desainer Swann Bourotte ini ditampilkan sebuah dekorasi kontemporer pada rumah tinggal. Tiga buah lampu yang disandingkan dengan bentuk yang meliuk-liuk terkesan hidup dan saling berkomunikasi satu dengan yang lain. Produk ini juga tidak nampak hanya sebagai sebuah lampu hias saja, tetapi juga menjadi bentuk slupture yang indah untuk dekorasi ruangan.

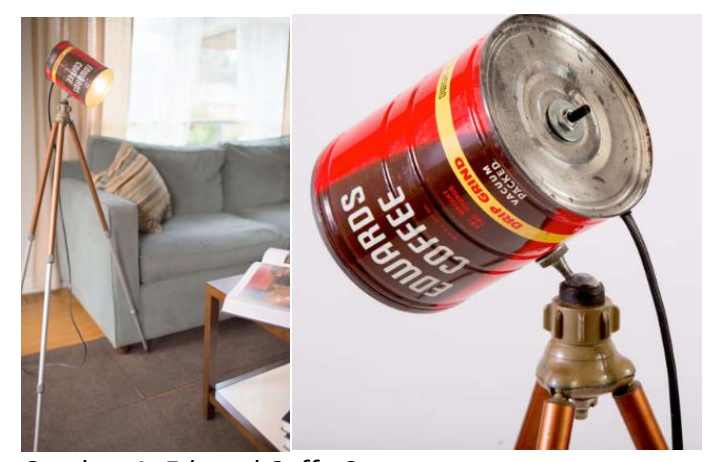

Gambar 4. Edward Coffe Can

(Sumber: www.trendhunter.com, 12/5/2016)

Pada gambar 4 terlihat sebuah rancangan reuse dari kalengn kopi yang difungsikan sebagai sebuah lampu lantai. Selain itu juga menggunakan sebuah tripod bekas sebagai penyangga lampu. Produk ini terkesan unik, antik dan personal karena tidak diproduksi masal dan bisa dimiliki oleh setiap orang.

Beberapa contoh di atas dapat menjadi ide atau konsep dalam membuat desain dari material onderdil kendaraan bekas, yang disesuaikan dengan perkembangan tren atau selera dan gaya hidup konsumen. Proses ide yang out of the box sangat diperlukan disini untuk dapat memunculkan produk-produk yang kreatif, inovatif dan dapat diterima oleh masyarakat. Produk yang tidak terikat dengan fungsi yang ada sebelumnya, tetapi tetap dengan tampilan visual yang menarik.

\section{Perancangan/Proses Desain}

Setelah dilakukan analisa data tren atau selera pasar, langkah selanjutnya adalah mengembangkan konsep berdasarkan data yang telah didapatkan. Data atau informasi desain digunakan untuk mencari ide untuk mengembangkan rancangan produk. Ide produk dikembangkan menjadi konsep desain, baik terkait dengan tampilan maupun dengan materian dan teknik produksi yang digunakan. Selain hal tersebut, perancangan dilakukan dengan melakukan pengamatan terhadap bahan onderdil bekas, melakukan penyusunan berbagai alternatif yang memungkinkan, dan pemilihan alternatif terbaik.

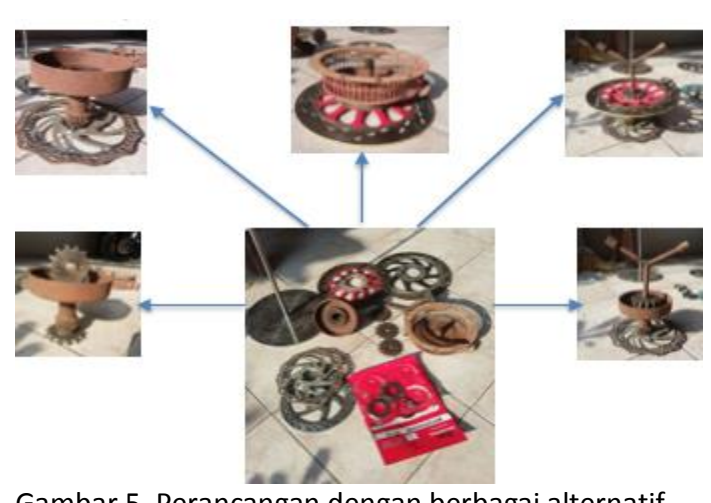

Gambar 5. Perancangan dengan berbagai alternatif susunan dari bahan yang sama

Selain itu juga dilakukan perancangan dengan proses designing, dengan hasil sebagai berikut:
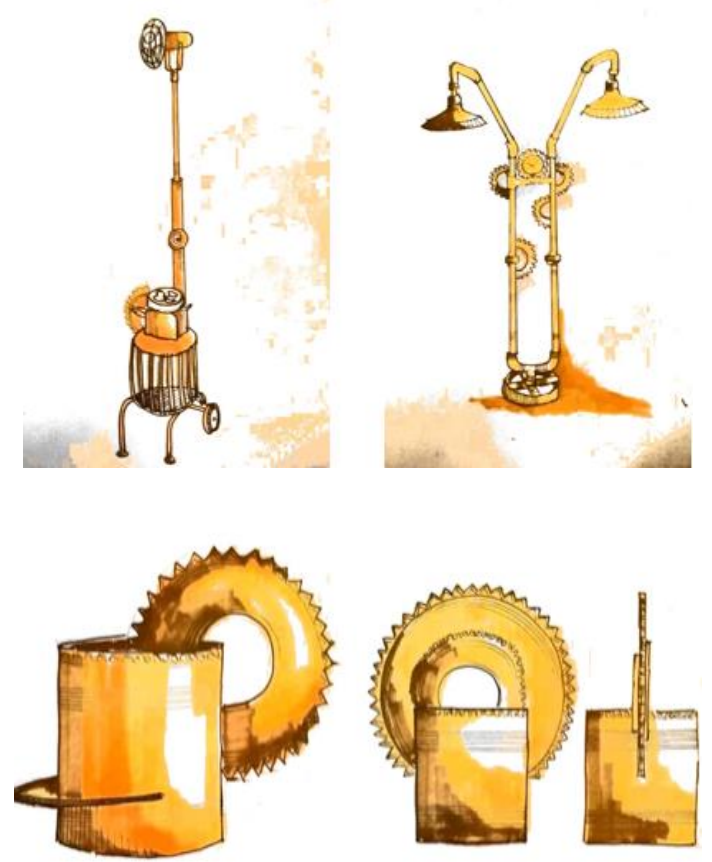

Gambar 6. Gambar hasil proses designing 


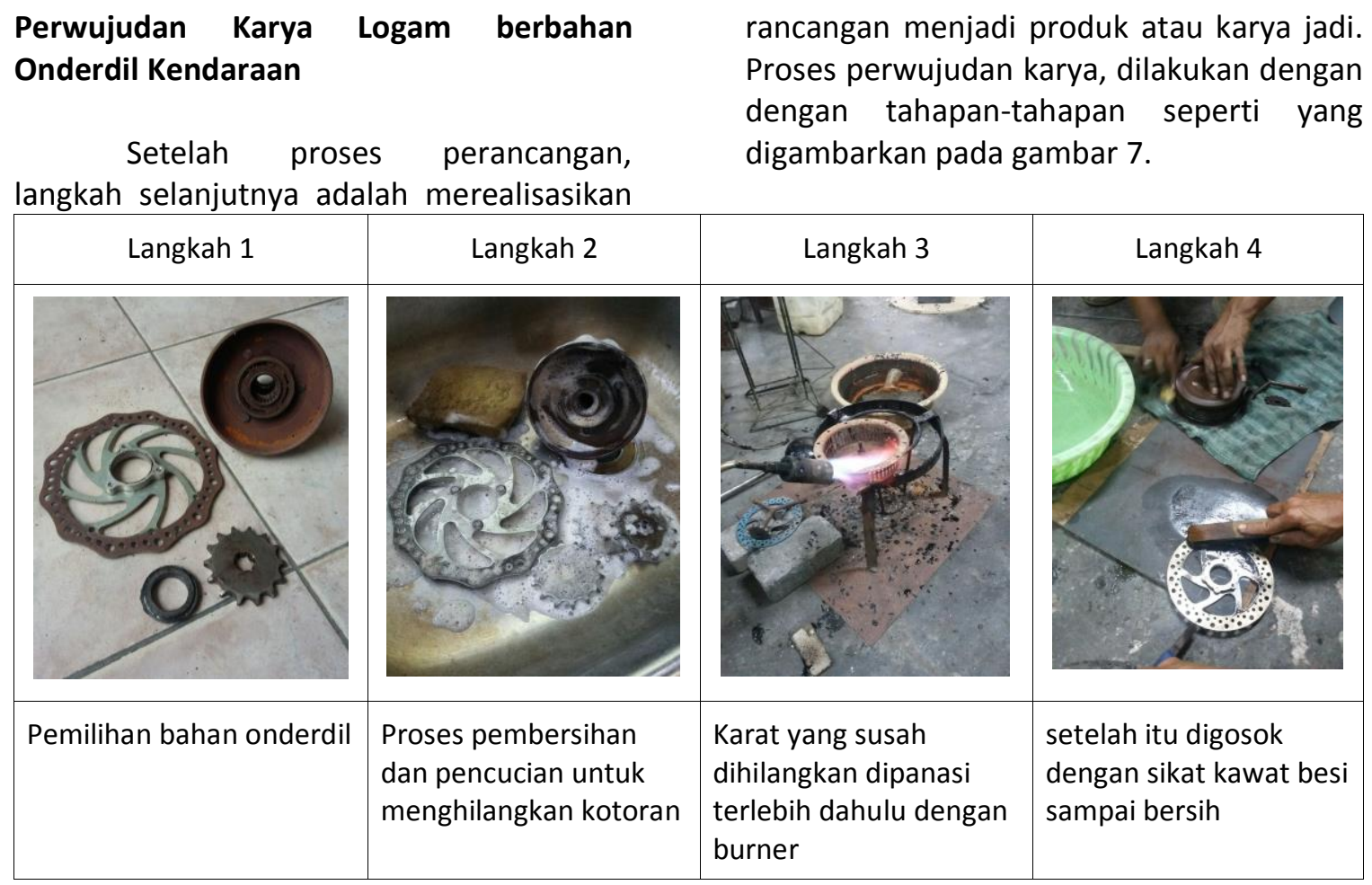

\begin{tabular}{|l|l|l|l|}
\hline \multicolumn{1}{|c|}{ Langkah 5 } & Langkah 6 & Langkah 7 \\
\hline $\begin{array}{l}\text { Onderdil yang telah } \\
\text { digosok kemudian dicuci } \\
\text { dan dikeringkan }\end{array}$ & $\begin{array}{l}\text { Onderdil } \\
\text { dirangkai/disusun } \\
\text { sesuai rancangan }\end{array}$ & $\begin{array}{l}\text { Onderdil yang telah } \\
\text { dirangkai kemudian } \\
\text { disatukan dengan Las }\end{array}$ & Produk hasil jadi \\
\hline
\end{tabular}

Gambar 7. Proses Perwujudan Karya

\section{Karya Kriya Logam berbahan Limbah Onderdil Kendaraan}

Hasil karya kriya logam berbahan limbah onderdil kendaraan yang berhasil diciptakan pada penelitian terapan ini sejumlah 7 buah terdiri dari berbagai bentuk dan fungsi, diantaranya adalah lampu hias, gantungan, dan hiasan meja, asbak, tempat lilin, dan penahan buku Beberapa hasil karya dapat dilihat pada gambar 8. 

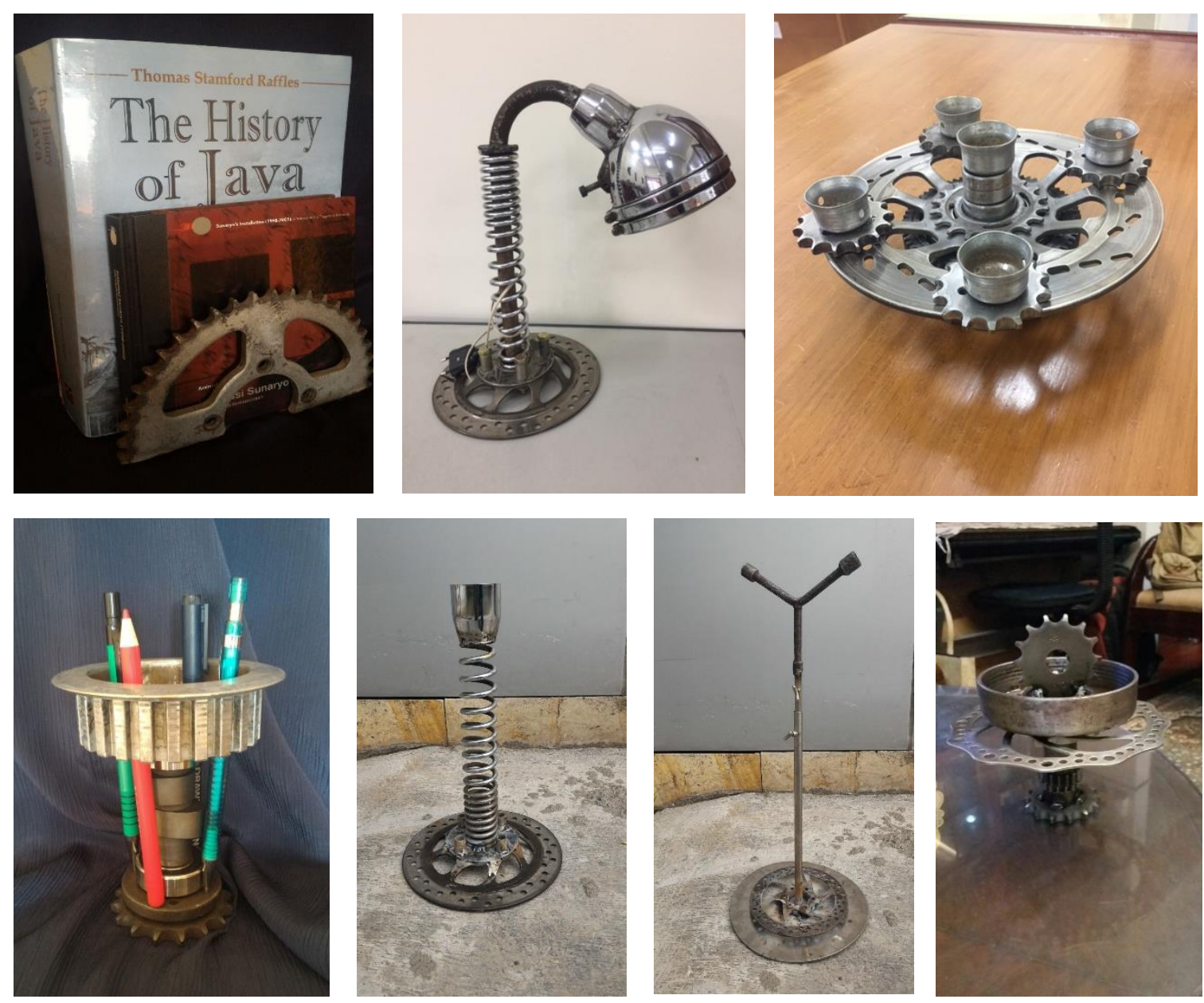

Gambar 8. Hasil Karya Kriya Logam berbahan Onderdil Bekas

\section{PENUTUP}

Berdasarkan hasil dari hasil penelitian dapat disimpulkan hal-hal berikut:

1. Penggunaan bahan onderdil bekas kendaraan bermotor dengan desain yang sesuai tren dalam penciptaan produk kriya logam akan memberikan keunggulan dan nilai ekonomis yang lebih baik.

2. Bahwa trend desain yang berkembang di dunia dapat dipelajari dari berbagai macam informasi yang bersumber dari perubahan mode dunia yang diciptakan oleh arsitektur, asesoris interior/eksterior dan lain-lain yang dapat dipejari dari buku, majalah, internet.

3. Berdasarkan eksplorasi peneliti terhadap trend dunia, dirumuskan tema yang cocok dengan penelitian ini, yaitu retro dan Tekno-Urban.

4. Dengan eksplorasi penciptaan desain berdasarkan prediksi trend yang akan berkembang di pasar maka diharapkan produk yang akan dibuat akan dapat diterima pasar dengan lebih baik.

5. Pada penelitian ini dihasilkan 7 karya kriya logam berbahan onderdil kendaraan bekas.

\section{Saran}

1. Dalam penciptaan produk yang akan dipasarkan baik lokal maupun internasional sebaiknya menggunakan pemahaman korelasi antara proses kreatifitas dengan membaca trend desain, pertimbangan reproduksi dan distribusi produk. 
2. Desain ini dapat diterapkan sebagai produk dalam uji coba pasar.

\section{DAFTAR PUSTAKA}

Eckenfelder WW, 1989,Industrial Water Pollution Control,Jr. McGraw-Hill Book Company

Feldman, E.B. 1967, .Art as Image and Idea. Englewood Cliffs, New Jersey: Prentice Hall Inc.

Harsono Wiryosumarta, 2008, Teknologi Pengelasan Logam, PT. Pradya Paramita, Jakarta.

Kosasih, M. dan Mattjik, Mutmainah, 2015, Perancangan Model Pengembangan Desa Industri Kecil Pemanfaatan Limbah Komponen Otomotif Berbasis Community Development, Proseding Makalah Seminar Nasional Sains dan Teknologi, Fakultas Teknik, Universitas Muhammadiyah Jakarta.

Moh. As'ad, 1987, Psikologi Industri: Sero IImu Sumber Daya Manusia, Liberti, Yogyakarta.

Panter, Barry (ed.), 1995,Creativity \& Madness: Psychological of Art and Artists, Aimed Press, American Institute of Medical Education, Burbank.

Setiyono, 2002, Sistem Pengelolaan Limbah B3 di Indonesia, Pusat Pengkajian dan Penerapan Teknologi Lingkungan (P3TL), Deputi Bidang TIEML, BPP Teknologi, Bogor.

Tata Surdia, Kenji Chijiwa, 2012, Teknik Pengecoran Logam, Penerbit Balai Pustaka, Jakarta.
Tim KSS, 1998, Mengelola Bengkel Mobil, Puspa Swara, Jakarta. 